\title{
Study About The Teaching Management Effectiveness Of Local General Colleges
}

\author{
Cui Liping ${ }^{1,}$ a \\ ${ }^{1}$ School of Literature, Baicheng Normal University, Baicheng 137000, China \\ aemail:cui4xj@126.com,*corresponding author
}

Keywords: College, Teaching management, Effectiveness

\begin{abstract}
In order to promote the teaching management effectiveness of higher education the paper proposes some managing suggestions about credit system, teaching quality, basic teaching construction and teaching research. The paper aims at inspiring the activeness of both teachers and students, constructing the stable teaching order, promoting teaching quality and efficiency, and guiding teaching practice.
\end{abstract}

\section{Introduction}

While the task of colleges is cultivating talent and the quality of talent cultivated is the lifeblood of colleges, the scientific formal teaching management is important guarantee of achieving the goal of talent-cultivating. The Ministry of Education issued Teaching Management Guidelines of Higher Education in 2003. The document is the guiding principle about normative organization system, contents and requirements of teaching management of higher education. It triggered interest in laws and methods of teaching management of higher education. Whereas either kind of management is means of efficiency, there should be clear purpose for each part of teaching management to improve the effectiveness of teaching management.

\section{Deepening the Reform of Credit System to Promote the Activity of Both Teachers and Students}

Decisions on deepening educational reform and advancing quality education fully by the CPC Central Committee and State Council was issued in June 1999, which pointed out explicitly that colleges should practice flexible learning mechanism and enable students finish their education in phases. According to the document, the most important reform of teaching management in colleges is credit system recent years. The advantages in theory are as follows. First, students study in a relaxed environment, after they have gotten enough both compulsory and optional credits they can study courses they like to get other credits in longer or shorter time than stipulated one. Second, it helps to advance quality education, optimize knowledge structure of students, and develop students' characteristics. Third, it helps to teach students in accordance with their aptitude, study independently, and inspire students' learning activity and initiatives. Forth, teachers' initiative is promoted consequently and they will try to improve teaching quality actively. Nevertheless, there are still some problems in credit system.

Elective system is the core of credit system. However, there are many limits when students choose courses. For example, besides limited elective courses, students can choose only one public elective course for each semester, thus they can only get enough credits of public elective courses by the seventh semester. Also, the major elective courses are generally arranged evenly for each semester; as a result, students cannot get enough credits until the seventh semester. In addition, teaching practice of normal colleges schedules generally at the 7th semester; and graduation thesis at the 8th semester. From the above, students can only get required credits in specified educational time objectively.

Electing both courses and teachers may promote enthusiasm of teaching and the teaching level of teachers. Actually, there are nearly none course provided by two or more teachers in our college 
since the number of teachers are limited. Students can choose only courses not teachers. More over the shortage of teachers influenced course construction. Though we have built a great number of public electives and professional ones they are far from that students need.

Colleges should deepen teaching management mechanism reform of credit system.

\section{Refining Teaching Running Management}

As stated in Teaching Management Guidelines of Higher Education by the Ministry of Education, teaching running management is the most important teaching management implemented according to teaching plan, which includes teaching process management and administrative management. Its basic point is this: for both the entire school stuff and students to coordinate and strictly implement teaching regulations so as to ensure stable running and quality of teaching[1]. The refining and enhancing of teaching running management is important insurance of stable teaching order.

As the expending of education evaluation of colleges, teaching management becomes more and more standardized. Each college makes own teaching running management regulations and improve them gradually. How to implement those regulations? There are dean's office, departments and teaching and research sections in teaching management hierarchy. In some colleges teaching and research sections does not participate truly teaching management of departments, and heads of the teaching and research section merely receive and dispatch documents or fill in statistics tables. To refine teaching running management and implement teaching regulations, teaching and research sections should function fully[2].

It is the premise of stable teaching order and the insurance for teaching and research sections to function that supervise and check effectively by dean's office and departments. Teaching and research section will not play its role effectively unless there are strict supervising from superior teaching management organization. Dean's office and departments may take regular, specific or random check. For regular check there should be summary and informing; for specific check there should be definite destination; and for random check typical cases should be grasped and coped with[3].

\section{Optimizing the Teaching Quality Management to Ensure and Promote the Teaching Quality}

The main task of teaching quality management is to implement the control of teaching quality which includes the programming of teaching plan, the implementing of teaching plan and curriculum, and other parts of teaching process. To optimizing the teaching quality management, all the regulations of teaching quality management and the system of teaching quality evaluation should be built rightly, the information of collecting, processing and feedback from each teaching step should be in time by applying modern information technology, and the teaching quality management should be standardized, scientific and institutionalized[4].

The key of teaching quality management is to improving the monitoring system of teaching quality. The monitoring system of teaching quality is a systematic engineering. It monitors the condition of requirement, implementation of process, and the goal of achieving according to the objective of personnel cultivation. When implementing the teaching quality monitoring system, the links of teaching input, teaching process and also teaching output should be focused on, and meanwhile, the quality monitoring should aimed at different sides and layers, so as to form a multi-dimensional and long lasting teaching quality monitoring system.

Following the principle of prevention first, the quality pre-control in teaching input implements the control from the source of teaching quality which includes teaching condition, teaching stuff and optimizing of teaching plan.

The content of teaching quality monitor is multidimensional and the type of the monitor is open and dynamic. To ensure the objectivity of class teaching quality evaluation, the evaluation pattern may adopt class assessment by students, visiting class by colleagues, visiting class by management, comprehensive information feedback, and evaluation by teacher self. Developing and processing evaluation should be emphasized in learning quality monitor of students. Teachers assess both 
knowledge and skill and potential develop ability of students during teaching activities.

Management in teaching output mainly refers to developing goal reached when students graduate. This may manipulate from examinations, graduation papers and graduates quality.

As for examination, the contents, forms and management of examination should be reformed. Good examination culture will led to good learning and teaching culture. As for graduation papers, the rules of thesis beginning, guiding, estimating and defense should be strict so as to improve the practice ability of students. As the meantime, the rules of follow-up research on graduates should be built and improved. By means of survey, visiting employers, having symposium with employers regularly, presenting information feedback about graduates on campus network, and so on, we will know employers' estimations on graduates, graduates' proposals on college teaching, and society's opinions on talent-development. This will help us to reform the model of talent-development and improve the quality of graduates.

\section{Strengthening the Management of Basic Construction of Teaching}

Basic construction of teaching includes constructions of subject, disciplines, curriculum, teaching materials, practice teaching base, learning culture, teaching team and management system. They are the most important base of ensuring the quality of teaching.

Now that college teaching assessment focuses on key subjects, key disciplines, excellent courses, excellent teaching materials, and proportions of professional titles and academic credentials of teaching team, colleges take basic teaching construction very seriously. However, we center not only on the number of that but also on the content and quality of them. The emphasis of acceptance is not those forms and statistics but the contents and qualities of constructions. Structures of subjects and disciplines construction should be planed scientifically; curriculum construction should be planed and phased in gradually; construction of teaching materials should make a feasible plan in advance; the principle of practice teaching base construction is serving for teaching; learning culture construction should grasp firmly and continuously; teaching team construction should focus on improving the quality of whole stuff; and construction of teaching management system should establish rules and regulations from actual condition and improve them gradually in practice.

Above all, the basic teaching construction should base on college development objective and general plan and proceed down-to-earth. For every basic teaching construction some new measures should be proposed to form a good stable environment for teaching.

\section{Strengthening Teaching Research Management to Improve the Quality of Talent Development}

It is stated in Teaching Management Guidelines of Higher Education by the Ministry of Education that research of teaching and teaching management is the base of teaching management[1]. Research of teaching and teaching management is the common duty of teaching administrative personnel and teaching staff. The research should follow the laws and characteristics of teaching science and combine with reality of teaching and teaching management[1].

Since teaching administrative personnel of departments is the main body of teaching management of departments, their knowledge of management, capacity and quality directly relate to teaching management quality and the achievement of teaching management objectives. For the sake of cultivating competitive compound talent with high quality, there should be a teaching administrative stuff with high quality in departments to conduct directing, making decisions, organizing, cooperating and serving. Colleges should take effective measures to encourage and support teaching administrative personnel take business training and learn teaching management knowledge, so as they can research and explore features and laws of theory and method of modern teaching management and apply them in teaching management practice[5].

Teaching reform must carry through the education policy of our party and follow up the fundamental laws of higher education. New situations arising in the reform should be studied 
scientifically and strictly to seek the truth and do practically.

Teaching research management covers project application, project review, funds management, project inspection, project acceptance, etc. Generally the project management of education and teaching research is the duty of executive president and its daily administration is the duty of the dean' office. Departments should include those projects passed in their annual work plan and implement organization, coordination, inspection and widespread application regularly. Only by focusing on guiding practice in formulation, mid-term review and acceptance of projects, can teaching research play its role effectively of improving teaching.

\section{Reference}

[1] The Points of College Teaching Management, The State Department of Higher Education. 33 (1998)

[2] Cao Aiping, Some Thoughts on Strengthening the University Department Teaching Management, J. Journal of Shangdong College of Education. 1 (2003) 82-83

[3] Zhou Min, On the Management of Teaching Process in Universities, J. Journal of Guangxi University. 6 (2001) 14-17

[4] Undergraduate Teaching Quality and Teaching Reform Project, Department of Higher Education. 1 (2007)

[5] Some Opinions on Strengthening Undergraduate Teaching Work to Improve the Quality of Teaching, Department of Higher Education. 4 (2001) 